Undas Vol 12. , Nomor 2 , Desember 2016 : 1--10

\title{
TINDAK TUTUR KEKERASAN SAAT SARIK DALAM BAHASA BANJAR
}

\author{
Speech Acts Violence in Banjar Language
}

\author{
Rissari Yayuk \\ Balai Bahasa Kalimantan Selatan \\ Jalan Jenderal Ahmad Yani Km 32,2, Loktabat, Banjarbaru 70712 Kalimantan Selatan \\ Telepon (0511) 4772641, Pos-el:yrissariyayuk@yahoo.co.id \\ HP: 085651077719
}

\begin{abstract}
Abstrak: Penelitian ini membahas tindak tutur kekerasan dalam Bahasa Banjar. Masalah yang dibahas dalam penelitian meliputi 1) bagaimana wujud tindak tutur kekerasan mengancam bahasa Banjar. 2) bagaimana wujus tindak tutur kekerasan meremehkan bahasa Banjar. Tujuan penelitian adalah untuk mendeskripsikan 1) wujud tindak tutur kekerasan mengancam dalam bahasa Banjar. 2) wujud tindak tutur kekerasan meremehkan dalam bahasa Banjar .Teknik yang digunakan dalam pengambilan data adalah teknik lapangan, rekam dan dokumentasi. Teknik ini digunakan untuk mendapatkan data lisan dan tertulis sebagai pendukung kajian. Data diambil dari tuturan langsung masyarakat Banjar yang berlokasi di Banjarmasin, Banjarbaru dan Kabupaten Hulu Sungai Selatan. Pengambilan data dilaksanakan pada bulan Januari 2016 -- Maret 2016. Berdasarkan hasil penelitian, tindak tutur kekerasan dalam bahasa Banjar meliputi mengancam diwujudkan dengan ancaman suatu aktivitas, seperti akan menyumpal atau melempar sesuatu kepada mitra tutur. Sementara untuk tindak kekerasan meremehkan, di gunakan kata makian perumpamaan hewan dan benda yang memiliki nilai rendah .Tindak tutur ini bisa dilakukan oleh orang tua kepada anak dan antar anggota masyarakat lainnya.
\end{abstract}

Kata kunci: Tindak Tutur, kekerasan, Banjar

Abstract: This studt entitled speech acts violence in Banjar language. The problem which are discuss 1) how a form speech acts in Banjar language, 2) how a form speech acts of violence underestimate in Banjar language. The aims of this study are the describe 1) the realization form speech acts in Banjar language, 2) the realization form speech acts of violence underestimate in Banjar language. This study is categorized in descriptive qualitative study. The are gained from recording and documentation from January until Marc 2016. This technique is used to obtain the data of oral and ewitten as a supporter of the study. Data taken from the direct speech Banjar community located in the data taken from oral speech communities in Banjarmasin, Banjarbaru and Hulu Sungai Selatan. The result shows that the acts of violence in Banjar language which includes threatening realized with the threat of an activity, such as going to gag or throw something to the hearer. As for violence underestimate, using cuss word parable animals and objects that have a low value. Speech actssaid this could be done by parents to children and between other members of society.

Key words: Speech acts, violence, Banjar 


\section{PENDAHULUAN}

Masyarakat Banjar paling banyak jumlahnya di Provinsi Kalimantan Selatan. Bahasa yang mereka gunakan sehari-hari adalah bahasa Banjar. Sebagai sebuah bahasa perhubungan, baik di lingkungan keluarga atau masyarakat, bahasa ini masih bertahan di tengah masyarakat penuturnya hingga sekarang.

Penggunaan ujaran dalam bahasa Banjar di lingkungan keluarga tidak selamanya tersusun dari kata-kata yang santun, bisa saja kata-kata yang dipilih dalam ujaran tersebut memiliki makna yang bisa menyakitkan hati. Penggunaan ujaran yang tidak santun ini bisa disebabkan berbagai faktor. Contoh saat orang tua sarik' marah' kepada anaknya menyebabkan ujaran yang dikeluarkan pun tidak pada tempatnya, diiringi nada tinggi, ungkapan jorok yang bisa merendahkan.

Djawanai (2001:68-69) menyatakan “ tindakan berbahasa bagian dari tingkah laku manusia dan dalam tingkah laku itu sangat mungkin orang melakukan sesuatu yang dapat dikategorikan sebagai serangan verbal (verbal attack) kepada orang lain yang tak lain merupakan suatu tindak kekerasan.

Tindak tutur kekerasan yang mengandung kata-kata tidak pada tempatnya dalam bahasa Banjar menarik untuk dikaji lebih dalam. Sepengetahuan peneliti kajian ini belum ada yang mengangkatnya menjadi sebuah penelitian. Kajian ini penting dilakukan 1) sebagai wujud kepedulian akan pelestarian bahasa daerah dan dapat memperkaya khazanah penelitian bahasa daerah. 2) penelitian ini penting dilakukan sebagai upaya pendokumentasian tindak ujar bahasa Banjar yang selama ini masih sedikit dikaji .

Di samping itu hasil penelitian ini dapat dijadikan 1) materi perbandingan untuk menghindarkan anak dari penggunaan kosa kata yang tidak santun. 2) Hasil penelitian ini diharapkan akan memberi manfaat bagi penelitian lainnya yang berdasarkan teori pragmatik.

Penelitian ini mengangkat judul Tindak Tutur Kekerasan dalam Bahasa Banjar. Masalah yang dibahas meliputi 1) bagaimana wujud tindak tutur kekerasan mengancam bahasa Banjar. 2) bagaimana wujud tindak tutur kekerasan meremehkan bahasa Banjar . Tujuan penelitian adalah untuk mendeskripsikan 1) wujud tindak tutur kekerasan mengancam bahasa Banjar, 2) wujud tindak tutur kekerasan meremehkan bahasa Banjar .

Penelitian yang berkaitan dengan tindak tutur berbahasa sudah pernah dilakukan, penelitian tersebut tersebut yaitu Kesantunan Direktif Bahasa Banjar oleh Ahmad Zaini (2010) dan Musdalifah pada tahun 2010 dengan judul "Kesantunan Meminta dalam Bahasa Banjar". dan pada tahun 2012 Rissari Yayuk meneliti "Maksim Kesopanan dalam Tuturan Penumpang dan Tukang Ojek di Pasar Hanyar Kota Banjarmasin". Pada penelitian Zaini (2010) dan Musdalifah (2010) mengupas tentang realisasi penerapan kesantunan dalam bahasa Banjar. Penelitian Yayuk (2012) mengkaji tentang pelaksanaan maksim kesantunan pada tuturan penumpang dan tukang ojek di Pasar Hanyar. Penelitian-penelitian tersebut 
berfokus pada kesantunan dalam tindak tutur berbahasa tidak membahas mengenai tindak tutur kekerasan dalam bahasa Banjar.

\section{KERANGKA TEORI}

\section{Tindak Tutur}

Leech dalam Jumadi (2005:115) menyebutkan tindak tutur atau speech act merupakan suatu tindakan yang diungkapkan melalui bahasa yang disertai dengan gerak dan sikap anggota badan untuk mendukung maksud pembicara. Tindak tutur ditentukan oleh adanya beberapa aspek situasi ujar, antara lain (1) yang menyapa (penutur) dan yang disapa (petutur); (2) latar belakang; (3) tujuan sebuah tuturan; (4) bentuk tindak kegiatan; (5) produk tindak verbal.

Aktivitas bertutur dengan segala aspeknya di atas oleh Keith Alan (dalam Rahardi, 2009:22) disebutnya dengan kegiatan yang berdemensi sosial. Sebagai sebuah proses komunikasi, proses bertutur ini akan berjalan dengan baik semua peserta tutur telibat aktif. Karena itu perlu kerjasama yang kuat antar peserta tutur salah satunya adalah dengan berperilaku sopan atau santun.

\section{Tindak Tutur Kekerasan}

Kekerasan ada yang bersifat simbol, fisik, dan verbal. Khusus kekerasan verbal adalah kekerasan yang menggunakan bahasa dan unsur-unsur bahasa lainnya
(Baryadi, 2012:36). Bateson (1972:82) menyatakan bahwa katakata itu bertuah dan memiliki kekuasaan dan kekuatan yang dapat digunakan untuk melakukan kekerasan yang mungkin dapat membawa akibat menyakitkan dan menimbulkan derita.

Tindak tutur kekerasan adalah tindak verbal. Baryadi (2012:39) menyatakan kekerasan verbal dapat menyebabkan ketidakstabilan suasana psikologis penerima, seperti kecewa, rendah diri, minder, agresif, dll.Kekerasan verbal berakibat luka psikis pada korbannya.

Salah satu wujud dari kekerasan verbal adalah tindak tutur kekerasan secara langsung. Tindak ini menimpa langsung kepada korbannya saat peristiwa komunikasi terjadi. Austin dalam (Baryadi, 2012:40 ) menyatakan setiap tindak tutur kekerasan tentunya mengandung tiga aspek. Contoh makian seorang ayah kepada anaknya "Dasar tidak becus". Melalui tindak tutur makian ini sang ayah mengungkapkan bahwa anaknya bodoh atau tidak mampu (tindak lokusi). (ii) melakukan perbuatan merendahkan martabat anaknya sebagai anak bodoh dan tidak mampu (tindak ilokusi), (iii) mempengaruhi jiwa anaknya sehingga anaknya menjadi rendah diri, serba salah dan lama-kelamaan anak bisa benar-benar merasa bodoh dan tidak mampu.

Leech dalam Baryadi (2012;36) menyatakan tindak tutur kekerasan 
termasuk tindak tutur konfliktif, yakni tindak tutur yang bertentangan dengan tujuan sosial, seperti menakuti, mengutuk,meremehkan, mengancam, menghina, memaki, dll.

Pada penelitian ini hanya mengkaji tindak tutur kekerasan mengancam dan memerintah. Baryadi menyatakan (2012: 38) tindak tutur mengancam dan meremehkan adalah termasuk tindak menekan atau mengintimidasi mitra tutur. KBBI $(2002 ; 45)$ menyebutkan mengancam atau ancaman menyatakan maksud untuk melakukan sesuatu yang merugikan, menyulitkan, menyusahkan, atau mencelakakan pihak lain. Sementara itu, meremehkan mengandung maksud membuat pihak lain menjadi tidak berharga atau menjadi rendah.

\section{METODE PENELITIAN}

Metode yang digunakan dalam penelitian ini adalah metode deskriptif kualitatif analitis. Metode ini dipilih karena penelitian ini dilakukan untuk mendapatkan gambaran secara alamiah mengenai tindak kompetitif pada masyarakat Banjar. Data yang dikumpulkan berbentuk deskripsi percakapan penutur bahasa Banjar dalam ragam situasi dan kondisi. Pengumpulan data dilakukan dengan cara pengamatan dan perekaman. Pengamatan dan perekaman ini dilakukan untuk membuat catatan atau dokumentasi dari lapangan secara langsung atas apa yang dilihat, dialami, dan dipikirkan dari data primer. Data sekunder dalam tulisan ini adalah literatur yang diperoleh secara tidak langsung untuk mendukung penulisan pada kajian ini melalui dokumen atau catatan yang berhubungan dengan bahasa Banjar.Pengambilan data dari Januari 2016 s.d. Maret 2016.

Teknik yang digunakan dalam tulisan ini adalah pengambilan sampel purposive sampling, yaitu teknik pengambilan sampel sumber data dengan pertimbangan tertentu (Sugiyono, 2009:300). Penetapan sampel tidak didasarkan keterwakilan dalam hal jumlah responden (besar sampel), tetapi berdasarkan kualitas atau ciri-ciri responden yang ingin diwakili.

Berdasarkan metode dan teknik di atas, penulis menempuh tiga langkah kerja, yaitu tahap pengumpulan data, pengolahan data, dan tahap penyajian hasil analisis data, hal ini sesuai pula dengan yang dimaksudkan Sudaryanto (2003:57). Data yang telah dikumpulkan selanjutnya diperiksa secara selektif berdasarkan permasalahan yang ada, data terpilih ini dianalisis disesuaikan dengan teori pragmatik, dan disajikan dengan metode informal atau kata-kata biasa.

Populasi penelitian ini adalah masyarakat Banjar yang berlokasi di Banjarmasin, Banjarbaru, dan Kabupaten Hulu Sungai Selatan . Penetapan sampel tidak didasarkan keterwakilan dalam hal jumlah responden (besar sampel), tetapi 
berdasarkan kualitas atau ciri-ciri responden yang ingin diwakili.

\section{ANALISIS DAN PEMBAHASAN}

\section{Tindak Tutur Kekerasan Mengancam}

Berdasarkan hasil penelitian, contoh tindak tutur kekerasan mengancam saat sarik 'marah'yang terdapat dalam bahasa Banjar dapat dilihat pada data berikut

\section{Data [1]}

P: Aku nih urangnya kada panyaman mandangar mulut pinda mucil tuh, kaluaha ku sumpal lawan lumbuk, nyaman tahu rasa'.(1)

'Saya ini orangnya tidak suka mendengar mulut yang bawel, kalau-kalau nanti saya sumpal dengan cabe, biar tahu rasa'.

MT: Piyan jua pang manyalahakan ulun tarus, ulun kada tarima.

'Anda sih terus menyalahkan saya, saya jadi tidak terima'

Konteks tuturan:

Tuturan terjadi di dalam sebuah rumah, antara seorang ibu dengan anaknya.

Pada data [1] tuturan (1) terjadi di dalam sebuah rumah, antara seorang ibu dengan anaknya. Ketika itu si anak dianggap ibunya melakukan suatu kesalahan, dia dituduh sebagai pelaku yang suka mengotori rumah, memotongmotong bunga di pekarangan, dan senang bermain saja. Mendapat tuduhan tersebut si anak merasa tidak terima, dia menganggap tuduhan ibunya atau penutur sangat berlebihan. Untuk mengungkapkan hal tersebut, mitra tutur mengomel sendiri di depan sang ibu. Piyan jua pang manyalahakan ulun tarus, ulun kada tarima ('Anda sih terus menyalahkan saya, saya jadi tidak terima') .

Sementara saat itu penutur sedang mengolek cabe persipan untuk makan siang.

Mendengar omelan si anak yang berisi informasi ketidakterimaan akan apa yang dituduhkan penutur, maka penutur mengeluarkan ujaran yang keras. Penutur sarik 'marah' besar. Aku nih urangnya kada panyaman mandangar mulut pinda mucil tuh, kaluaha ku sumpal lawan lumbuk, nyaman tahu rasa'(1) ('Saya ini orangnya tidak suka mendengar mulut yang bawel, kalau-kalau nanti saya sumpal dengan cabe, biar tahu rasa').

Penanda tindak tutur kekerasan pada ujaran yang diungkapkan dalam kondisi emosi marah ini terdapat pada intonasi keras dan penggunaan kata ancaman kaluaha ku sumpal lawan lumbuk, nyaman tahu rasa ('Saya ini kalau-kalau nanti saya sumpal dengan cabe, biar tahu rasa'). Penutur mengancam akan menyumpal mulut mitra tutur dengan cabe yang sedang dioleknya jika terus-terusan ngomel.Bahkan penutur sekanakan menunjukkan rasa puas jiwanya jika cabe tersebut benarbenar disumpalkan 'biar tahu rasa'.

Pada tindak ujar kekerasan seorang ibu kepada anaknya ini mengandung tiga aspek. (i) melalui 
tuturan tersebut si ibu mengungkapkan bahwa akan menyumpal cabe ke mulut mitra tutur atau anaknya jika tidak berhenti mengomel (tindak lokusi), (ii) melakukan perbuatan mengancam, yaitu mengintimidasi mitra tutur yang bisa membuat celaka, (iii) menyebabkan rasa takut bahkan kemungkinan rasa benci karena dituduh di bawah ancaman.

\section{Data [2]}

P: Dasar bungkul ikam nih, baulanja tarus, gawiaannya manangis pulang, kucatuk lawan katungkang jua nih mun masih kaya itu tarus. (1)

Dasar bodoh kamu ini, belanja terus, kerjanya menangis juga, saya pukul dengan batok kelapa kalau masih seperti itu.

MT: iih hah. (menangis tersedusedu) 'Iya.' (2)

Konteks:

Tuturan terjadi di tepi jalan raya antara seorang ibu yang profesinya pengemis kepada anaknya yang sedang belanja sate

Data [2] pada tuturan (1) terjadi di tepi jalan raya antara seorang ibu yang profesinya pengemis kepada anaknya yang sedang belanja sate. Ketika itu si ibu sedang menyusui seorang bayi di bawah pohon kelapa yang teduh. Sementara anaknya yang lain dengan tubuh tanpa baju terlihat begitu lahap memakan sate. muka anak itu terlihat kotor dengan biluran kehitaman bekas air mata di pipinya.Tiba-tiba penutur berujar dengan keras Dasar bungkul ikam nih, baulanja tarus, gawiaannya manangis pulang, kucatuk lawan katungkang jua nih mun masih kaya itu tarus, ('Dasar bodoh kamu ini, belanja terus, kerjanya menangis juga, saya pukul dengan batok kelapa kalau masih seperti itu').

Entah apa yang ada di pikiran penutur sehingga dia mengucapkan makian bodoh kamu yang berisi ancaman saya pukul dengan batok kelapa kalau masih seperti itu . Emosi tinggi terlihat dari wajah penutur yang merah padam. Tangannya sebelah memeluk bayinya, sebelah lagi memegang batok kelapa. Ancaman sepertinya akan dilaksanakan. Namun untunglah mitra tutur menyadari akan terlaksananya ancaman tersebut, dia langsung menghentikan berbelanja sate dan melanjutkan pekerjaan mengemisnya di tengah jalan yang letaknya berdekatan dengan lampu merah.

Pada tindak ujar kekerasan seorang ibu kepada anaknya ini mengandung tiga aspek, yaitu (i) melalui tuturan tersebut si ibu mengungkapkan bahwa akan memkul anaknya jika tetap senang belanja dan menangis (tindak lokusi), (ii) melakukan perbuatan mengancam, yaitu mengintimidasi mitra tutur yang bisa membuat celaka, yakni kepala si anak bisa bocor jika kena lemparan batok kelapa yang terlihat siap untuk dilemparkan si ibu (ilokusi), (iii) anak menjadi selalu ketakutan jika menangis dan akan belanja. 


\section{Tindak Tutur Kekerasan Meremehkan}

Berdasarkan hasil penelitian, contoh tindak tutur kekerasan meremehkan saat sarik 'marah'yang terdapat dalam bahasa Banjar dapat dilihat pada data berikut

\section{Data [3]}

P: Satua nyawa nih, parak ha taranjah unda.

'Monyet kamu nih, hampir tertabrak saya.'(1)

MT: Situ jua nang nang kada balilihat, dasar picak. urang sudah di pinggir bajalan, nyawa nang sing lajuan, anjing nyawa.

'Situ juga yang tidak melihat, dasar buta, orang sudah di tepi jalan berjalan, kamu yang terlalu ngebut, anjing kamu. (2)

Konteks:

Tuturan terjadi di sebuah gang kecil di kota Banjarmasin antara pengendara dan penjalan kaki.

Data [3] pada tuturan (1) terjadi di sebuah gang kecil di kota Banjarmasin antara pengendara dan penjalan kaki.Saat itu hampir magrib. Penutur melaju dengan kencang di sebuah gang tanpa peduli kalau ada beberapa orang yang sedang lewat di sana. Ketika kendaraanya hampir menabrak mitra tutur, penutur terkejut dan mengeluarkan tuturan kekerasan Satua nyawa nih, parak ha taranjah unda 'Monyet kamu nih, hampir tertabrak saya'.

Penanda tuturan [3] memiliki ujaran kekerasan, yaitu penggunaan kata Satua nyawa nih' monyet kamu ini'. Ujaran ini dikeluarkan dalam keadaan emosi tinggi. Intonasi keras berwujud kalimat yang nyaring terdengar sampai ke luar gang. Penutur mengatakan mitra tuturnya adalah seekor monyet. Dalam budaya Banjar penggunaan istilah monyet untuk menyamakan diri seseorang ini dianggap penghinaan keras. Penutur telah meremehkan mitra tutur serendah-rendahnya. Akibatnya mitra tutur membalas ujaran keras tersebut dengan lebih keras lagi Situ jua nang kada balilihat, dasar picak. urang sudah di pinggir bajalan, nyawa nang sing lajuan, anjing nyawa ('Situ juga yang tidak melihat, dasar buta, orang sudah di tepi jalan berjalan, kamu yang terlalu ngebut, anjing kamu').

Pada tindak ujar kekerasan seorang pengendara kepada pejalan kaki ini mengandung tiga aspek, yaitu (i) melalui tuturan tersebut penutur atau pengendara mengungkapkan bahwa mitra tutur tak ubahnya seekor monyet yang telah membuat penutur hampir menabrak (tindak lokusi), melakukan perbuatan meremehkan, yaitu penutur merendahkan mitra tutur (ilokusi), (iii) yang berakibat rasa malu dirasakan mitra tutur

\section{Data [4]}

P: Uh Utuh hirang, ikam nih makin hari makin mamburit rinjinglah. Jar $k u$ apa jangan saharian maunjun, tuh kada ingat lagi balajar.

'Hai Utuh Hitam, kamu ini makin hari makin memantat wajan ya. Kataku apa jangan seharian memancing, itu sampai melupakan belajar' (1) 
MT: Uma Bah purunnya piyan manyambati ulun kaya itu, hirang-hirang ulun anak piyan jua kalu.

'Aduuh Bapak teganyanya Anda menjelekan saya seperti tu, hitam-hitam saya anak Bapak juga kan.'(2)

Konteks:

Tuturan terjadi di sebuah rumah antara bapak dan anak

Data [4] pada tuturan (1) terjadi di sebuah rumah antara bapak dan anak. Saat itu, si anak atau mitra tutur baru saja pulang dari sawah, Dia baru selesai memancing. Aktivitas memancing memang menjadi pekerjaannya seharihari. Sehabis pulang sekolah, di hari yang biasanya begitu panas, penutur tidak segan untuk memancing dari sawah ke sawah atau dari kali ke kali. Akibatnya, bila malam hari penutur menjadi kelelahan dan cepat tertidur. Dia tidak bisa belajar lagi. Melihat keadaan ini penutur atau ayahnya menjadi marah. Hingga pada sore itu keluarlah ujaran Uh Utuh hirang, ikam nih makin hari makin mamburit rinjinglah. Jar ku apa jangan saharian maunjun, tuh kada ingat lagi balajar

('Hai Utuh Hitam, kamu ini makin hari makin memantat wajan ya. Kataku apa jangan seharian memancing, itu sampai melupakan belajar') .

Ujaran yang mengandung tindak kekerasan terlihat pada penggunaan mamburit rinjing ('pantat wajan'). Wajan adalah benda untuk menggoreng sesuatu. Pantat wajan biasanya hitam legam. Ungkapan ini menjadi pilihan kata bagi penutur untuk mengekspresikan rasa marahnya kepada si mitra tutur yang tidak peduli belajar namun lebih memilih memancing. Padahal hasil memancing tidak seberapa, belajar terganggu, dan badannya semakin hitam kena sengatan matahari hampir di setiap harinya. Mimik wajah penutur terlihat keras. Intonasi yang tinggi menyertai ujaran ini. Penutur benar-benar sarik' marah' kepada mitra tutur.

Pada tindak ujar kekerasan seorang bapak kepada anaknya ini mengandung tiga aspek, yaitu (i) melalui tuturan tersebut penutur mengungkapkan bahwa mitra tutur memiliki kulit hitam legam seperti pantat wajan (tindak lokusi), (ii) melakukan perbuatan meremehkan, yaitu penutur merendahkan mitra tutur (ilokusi), karenanya mitra tutur tidak menerima dan berujar Uma Bah purunnya piyan manyambati ulun kaya itu, hiranghirang ulun anak piyan jua kalu ('Aduuh Bapak teganyanya Anda menjelekan saya seperti itu, hitam-hitam saya anak Bapak juga kan') (iii) yang berakibat rasa malu, diremehkan, dan dihina dirasakan mitra tutur.

\section{PENUTUP}

\section{Simpulan}

Wujud tindak tutur kekerasan saat sarik 'marah' dalam bahasa Banjar ini menggunakan penanda ancaman berupa ujaran dengan kata-kata yang mangandung makna akan melakukan sesuatu yang menyakitkan kepada mitra tutur dengan maksud mengancam mitra tutur dan disertai dengan intonasi keras, seperti pada data [1] kaluaha $k u$ sumpal lawan lumbuk, nyaman tahu rasa"Saya ini kalau-kalau nanti saya sumpal dengan cabe, biar tahu rasa'. Penutur mengancam akan menyumpal 
mulut mitra tutur dengan cabe yang sedang dioleknya jika terus-terusan ngomel. Demikian juga pada data [2] . Penutur dengan emosi tinggi berujar kepada mitra tutur Dasar bungkul ikam nih, baulanja tarus, gawiaannya manangis pulang, kucatuk lawan katungkang jua nih mun masih kaya itu tarus (1) Dasar bodoh kamu ini, belanja terus, kerjanya menangis juga, saya pukul dengan batok kelapa kalau masih seperti itu. Pada data ini penutur mengancam akan memukul kepala anaknya dengan batok kelapa jika terus menangis.

Wujud tindak tutur kekerasan meremehkan saat sarik 'marah' dalam bahasa Banjar ini menggunakan penanda ujaran meremehkan dengan kata-kata yang mengandung makna merendahkan mitra tutur yang disamakan dengan hewan, benda, atau sifat tertentu yang berkonotasi negative. Contoh data [3], penutur berujar Satua nyawa nih, parak ha taranjah unda 'Monyet kamu nih, hampir tertabrak saya'. Data [3] menggunakan kata monyet sebagai ungkapan menyamakan mitra tutur dengan hewan monyet. Demikian pula dengan data [4], Uh Utuh hirang, ikam nih makin hari makin mamburit rinjinglah. Jar $k u$ apa jangan saharian maunjun, tuh kada ingat lagi balajar 'Hai Utuh Hitam, kamu ini makin hari makin memantat wajan ya. Kataku apa jangan seharian memancing, itu sampai melupakan belajar' . Data [4] menggunakan penanda meremehkan mitra tutur, dengan menggunakan ungkapan mamburit rinjinglah 'memantat wajan'.Mitra tutur dianggap sehitam pantat wajan oleh penutur.

Tindak tutur kekerasan saat sarik'marah' dalam bahasa Banjar yang meliputi mengancam dan meremehkan ini menyebabkan ketidakstabilan suasana psikologis penerima, seperti kecewa, rendah diri, minder pada mitra tutur. Hal ini dapat dilihat dari tanggapan ujar mitra tutur yang berisi ketidakberterimaan. Tindak tutur kekerasan ini bisa dilakukan orang tua kepada anak, atau antar anggota manyarakat lainnya. Penyebab tindak tutur kekerasan ini digunakan karena adanya tingkat emosi anggota komunikasi yang tidak stabil (marah).

\section{DAFTAR PUSTAKA}

Baryadi, I.Praptomo. 2012. Bahasa, Kekuasaan, dan Kekerasan. Jogyakarta. Sanata Darma.

Bateson, Gregory. 1972. Step to an Ecology of Mind. New York: Ballantine.

Djawanai, Spephanus. 2001. "Bahasa dan Kekerasan". Dalam Sumijati AS (ed). Manusia dan Dinamika Budaya:dari kekerasan sampai Baratayudha. Yogyakarta:Fakultas Sastra UGM bekerjasama dengan BIGRAF Publishing. Halaman 49-72.

Jumadi.2005. Representasi Kekuasaan dalam Wacana Kelas. Jakarta. Pusat Bahasa. 
Musdalifah (Ed). 2010. "Kesantunan Meminta dalam Bahasa Banjar" dalam Undas. Banjarbaru:Balai Bahasa Banjarmasin.

Rahardi R. Kunjana. 2009. Pragmatik. Jakarta:Erlangga.

Sudaryanto. 2003. Metode dan Aneka Teknik Analisis Bahasa: Pengantar Penelitian Wahana Kebudayaan secara Linguistis. Yogyakarta: Duta Wacana University Press.

Sugiyono. 2009. Metode Penelitian. Bandung: Alfabeta.

Yayuk, Rissari. 2012. Pelanggaran Prinsip Kesantunan Supir Angkutan Umum Jurusan Martapura. Prosiding Seminar Kebahasaan dan Kesastraan Yokyakarta .Yoyakarta: Balai Bahasa Yogyakarta.

Zaini, Ahmad(Ed). 2010. “Kesantunan Direktif Bahasa Banjar” dalam Jurnal Undas 6(1): 34-46. Banjarbaru: Balai Bahasa Banjarmasin. 